\title{
Research on the Path of Innovation for University-Enterprise Cooperation under the Background of Agricultural Reclamation Reform
}

\author{
Ye Liu1*, Luan Shi² \\ ${ }^{1}$ Heilongjiang Bayi Agricultural University, Daqing, China \\ ${ }^{2}$ Heilongjiang Polytechnic, Haerbin, China \\ Email: *byndly@126.com
}

How to cite this paper: Liu, Y., \& Shi, L. (2020). Research on the Path of Innovation for University-Enterprise Cooperation under the Background of Agricultural Reclamation Reform. American Journal of Industrial and Business Management, 10, 1263-1270. https://doi.org/10.4236/ajibm.2020.107084

Received: June 24, 2020

Accepted: July 21, 2020

Published: July 24, 2020

Copyright (อ 2020 by author(s) and Scientific Research Publishing Inc. This work is licensed under the Creative Commons Attribution International License (CC BY 4.0).

http://creativecommons.org/licenses/by/4.0/ (c) (i) Open Access

\begin{abstract}
With the development of collectivization and farm enterprise in reclamation area, the separation of government and enterprise, society and enterprise, and management and management will be deepened gradually. The relationship between reclamation and universities will also change. The relationship between higher and lower levels of administrative management and fund allocation has become a parallel cooperation relationship. How to build a new type of cooperation relationship has become a new problem for universities and enterprises. Under the background of agricultural reclamation reform, how to adapt to the situation of agricultural reclamation reform, and how to build a new school enterprise cooperation relationship with Beidahuang group are studied. With the promotion of the reform of state-owned enterprises, the gradual deepening of the separation of government and enterprise, the separation of society and enterprise, and the separation of management and management, enterprises focus on the specialized operation of enterprises. After the separation of their universities, the financial support and policy support obtained in teaching, scientific research and school running funds will be greatly reduced. For local universities with limited school running resources, it is necessary to deal with learning well. The relationship between school, government and enterprise is very important to improve the quality of school running.
\end{abstract}

\section{Keywords}

University-Enterprise Cooperation, Agricultural Reclamation Reform 


\section{Introduction}

Since "the issuance of the guidance on deepening the reform of state-owned enterprises", the CPC Central Committee and the State Council have successively promoted the reform of state-owned forest farms and state-owned forest areas, the reform of agricultural reclamation, the reform of oil and gas and other fields. In these reforms, it is clearly proposed to divest the social function of running schools and transfer the running schools to territorial management. Due to specific historical reasons, these enterprises and the universities they run are mutually supportive and highly integrated. Enterprises provide a large number of funds for running schools, and places for teachers and students to practice and obtain employment for colleges and universities. Colleges and universities also provide human and intellectual support for the development of enterprises. Both sides have jointly created a rich spiritual culture. After the reform, how to maintain and innovate the cooperative relationship between schools and enterprises for many years and how to supplement the evacuation of enterprises and the shortage of funds and how to carry forward the spirit and culture created by school and enterprise are the urgent problems to be solved.

Throughout the researchers' research on the model between the reform and development of colleges and universities and the reform and development of enterprises, it is mainly aimed at the problems existing in the cooperation between schools and enterprises, the transformation of the functions of government enterprises and colleges, etc., which are all based on the problem-solving research based on the structural, institutional, financial and other difficulties faced by the development of higher education in China (Xu, 2018).

From the search of CNKI paper database, most scholars pay more attention to the talent training of Vocational Colleges when they study school enterprise cooperation, but not much on the application-oriented talents training universities. With the construction of application-oriented universities, the breadth and depth of school enterprise cooperation will inevitably become a new focus and innovation. There is little research on the cultural field of school enterprise cooperation. Heilongjiang Bayi Agricultural Reclamation University and Heilongjiang Agricultural Reclamation co-created the spirit of Beidahuang. This spirit is also the common values and cultural outlook formed by the cooperation and prosperity of both sides for many years. With the reform and development of agricultural reclamation, the spirit of Beidahuang will inevitably have new connotation with the deepening of reform and the development of enterprises.

\section{Research on School Enterprise Cooperation at Home and Abroad}

\subsection{Research and Development of School Enterprise Cooperation in Foreign Countries}

The cooperation between universities and enterprises in foreign countries has a history of one hundred years. It plays an important role in higher education. It is 
the successful experience of higher education in developed countries, and can play a complementary role in personnel training (People's Daily, 2018).

German "dual system" model: The "dual system" mode is the earliest school enterprise cooperation mode in the world. It combines the traditional "Apprentice" training mode with the three modern vocational education ideas, and is a vocational education mode of cooperation between enterprises and schools (Wang, 2016).

The mode of "work study alternation" in England: The British government launched enterprises to participate in vocational education, and jointly established vocational schools and vocational training institutions, which is an important measure in the reform of vocational education.

The business education com pacts model in the United States. It started from the University of Cincinnati. It is a mutually beneficial cooperative relationship established by the education department, colleges, enterprises, business associations and other organizations of the US government through negotiation.

South Korea's mode of "industry university cooperation": Korean government stipulates that enterprises must participate in vocational education, and all enterprises with more than 1000 employees shall be responsible for on-the-job training of employees; enterprises with less than 1000 employees shall pay employment insurance to the state at $0.75 \%$ of the average wage of employees (Liu \& Liu, 2009).

\subsection{Research and Development of School Enterprise Cooperation in China}

As early as 1985, our country has attached great importance to the integration of production, learning and research, and deepened the cooperation between schools and enterprises. From the perspective of education system reform, it formally proposed that universities, enterprises and institutions, and local governments should carry out joint school running. In 1991, China Industry University Research Cooperative Education Association was established in Shanghai, marking the further promotion of the industry university research mechanism. In 2006, the national " $11^{\text {th }}$ Five Year Plan" proposed "vigorously develop employment oriented, vigorously promote the school enterprise cooperation, the combination of work and learning talent training mode" (China News Network). Ye min and others' new business form and new engineering; Shi Xiaoqiu and others' new integration, open and adaptive local colleges and universities' new engineering system construction thinking; Li Maoguo's integration of science and education teaching mode: current situation and countermeasures; Yang Yigang's research on the improvement of engineering 4 education and training mode aiming at improving the ability to solve "complex engineering problems" and $\mathrm{Li}$ Zhifeng's research on the cultivation of young teachers' engineering and technical ability: field, habits and organizational improvement discussed how to construct a new manufacturing industry from different perspectives. The con- 
sensus reached is that the core strategy is industry, university and research, and the enterprise is the strategy drive, pay attention to the landing of scientific research results and entering the enterprise, school enterprise cooperation is to build the enterprise as the main body of production, learning and research.

Since the construction of "double first class", through deepening the mode of production, learning and research, the breadth and depth of school enterprise cooperation has been further expanded, covering personnel training, scientific research and cultural heritage, realizing the reconstruction of education mechanism that education serves the society, so as to realize the direct social influence of students, so as to cultivate talents in colleges and universities. In the construction of disciplines and specialties in colleges and universities, the integration with the development direction of enterprises is higher, and the support for the development of industries is higher. The main body of production, education and research returns to dynamic adjustment from single enterprise oriented, and the cooperation carrier also changes from the incubation of science and Technology Park and the adjustment of science and technology investment to the organic connection of education and social economic development, and the driving mechanism of social development returns to the further analysis of education "sharing economy" system.

From the current situation of school enterprise cooperation in China, with the in-depth promotion of the government, enterprises and schools, the level of cooperation is more in-depth than before, and the scope of cooperation is further expanded, but compared with the foreign school enterprise cooperation, it is still insufficient.

\section{Problems in School Enterprise Cooperation after Agricultural Reclamation Reform}

\subsection{Great Pressure on School Resources}

As far as the funds for the construction of universities in the south-east will be greatly reduced after the reform, the funds for the universities and colleges in the south-east will be greatly reduced, including those in the former provinces. In particular, after considering the enterprise reform, the enterprise development needs to set up application research projects (Educator, 2019), cannot set up basic scientific research projects, which is more significant for the school infrastructure transformation, investment in equipment and equipment, and will certainly form a new constraint on the scientific research and innovation of colleges and universities.

\subsection{The Operation Mechanism of Co-Construction Is Not Perfect}

In recent years, with the gradual implementation of the "2011 plan" and other measures, the depth and breadth of cooperation between the school and the enterprise has been continuously expanded. However, there is a lack of overall planning in the top-level design in the process of cooperation. Enterprises and 
schools often only focus on the cooperation of single function and single field, such as building only one practice base for professional students and only building a scientific research cooperation platform in professional field. This is a big operation cost for colleges and enterprises, and also causes the organization operation is not strict and communication in the operation process Problems such as lack of smooth communication and coordination lead to cooperation in a mere formality, far from reaching the level of strategic cooperation.

\subsection{The Policy Incentive of School Enterprise Cooperation Is Not Enough}

The state-owned enterprises in the reform are all state-owned enterprises. In talent introduction and research cooperation, they tend to focus on domestic first-class universities or scientific research institutions, which brings greater pressure on local colleges and universities that need enterprise support. The system of school enterprise cooperation has not yet been fully established, and the government has not yet played a role in the cooperation. Moreover, in the development process of school enterprise cooperation, enterprises are the investors or the party providing internship practice conditions. The enthusiasm of cooperation is not high, and the lack of policy guidance and support from relevant aspects makes colleges and universities become the most active party in the cooperation, which easily leads to the craze of being picky The phenomenon of "hot first and then cold" will affect the cooperation effect.

\subsection{The Integration Depth of School Enterprise Cooperation Is Not High}

In the long-term running process of colleges and universities, a relatively perfect scientific research system and personnel training mode have been formed. Due to the long-term micro environment development, the overall development level of these enterprises' colleges and universities is not high, and there is a certain distance between them and the market-oriented needs of talents 6 and scientific and technological achievements. They have not yet achieved seamless connection, and cannot meet the practical needs of "coming to war, plug and play". In the process of school enterprise cooperation, colleges and universities often carry out practice in the graduation grade. Although it is conducive to students' employment, it cannot meet the requirements of improving students' practical ability in the reform of talent training mode, and cannot realize the virtuous cycle of theory practice theory practice.

\subsection{The Relevant System Is Not Perfect}

The system of college students' practice training and school enterprise cooperation is not perfect, the rights and obligations of both sides in school enterprise cooperation are not clear, the school undertakes too much responsibility and content, the enterprise only provides the opportunity of practice, and there is a blank system in related aspects. For example, a statistic shows that $44 \%$ of the 
students' internship work is unpaid, $38 \%$ are paid a little, and $10 \%$ are paid a certain amount. Therefore, to better stimulate the positive energy of school enterprise cooperation, the key is to improve the system $(\mathrm{Su}, 2018)$.

\section{Suggestions on Building a New Type of School Enterprise Partnership}

\subsection{Build the Whole Process of Enterprises to Participate in College Education and Teaching Mechanism}

Colleges and universities should adapt to the new needs of the development of education in the new era, and effectively turn the foothold of running a school to serve the local economic and social development, to integrate production and education with school enterprise cooperation, to cultivate compound application-oriented and technical skills talents, and to enhance the employment and entrepreneurship ability of students. Talent training is closely related to the industrial reform. Only by truly involving enterprises in the whole process of talent training, can enterprises truly realize the integrated education of school and enterprise ( $\mathrm{Lu}, 2018)$, from the formulation of talent training mode to the construction of double qualification team, from the construction of internal and external training bases, the introduction of factories to the school, to the establishment of long-term mechanism of joint training.

\subsection{The Service System for Colleges and Universities to Deeply Participate in the Reform of State-Owned Enterprises}

With the deepening of the reform of agricultural reclamation, some original organizational framework, operation mechanism and development concept have been broken. It is urgent to establish new ideas according to the reform and development of agricultural reclamation, and the focus of work will also be shifted to the promotion of the core competitiveness of enterprises. From relying on a single school to become more open, more cost-effective, and gradually pursuing high-end technology and talents, the original irreplaceable "soil experts" and the immutable talent training mode will change. Schools should participate in the reform process of state-owned enterprises, make seven plans for the reform and development, find development paths for the implementation of reform, and reform, transformation and development. To provide new technology and new driving force, we need to find the right position and serve the reform of reclamation accurately.

\subsection{The Government Sets up a Platform to Guide School Enterprises to Build a New Type of Cooperative Relationship}

Under the condition of collaborative development of enterprises and universities for many years, enterprises and universities have become mutually integrated, interconnected, symbiotic and common development, forming a common development gene. However, with the reform of agricultural reclamation and the 
separation of social functions, the advantages of schools in talent training base, continuing education and scientific research achievements have suddenly disappeared, and agricultural reclamation has no longer undertaken these responsibilities. The government should play the role of undertaking enterprises and colleges and universities, take the legislation of "College Students' internship regulations" as the starting point, continue to promote the system construction of receiving college students' internship training by Party and government organs, enterprises and institutions, social service institutions, etc., tighten the relationship between the two sides, make good use of the original cooperation foundation, and truly make the three parties become beneficiaries (Liu, 2017).

\subsection{Integrate Cultural Heritage and Innovation into School Enterprise Cooperation}

For a long time, the integration and development of "one family" has formed mutual recognition of cultural concepts, personnel training specifications and scientific research directions. The school has integrated advanced corporate culture and production needs into the whole process of talent training and scientific research. The school's platform and team are needed to inherit and innovate corporate culture inheritance and development. Therefore, both sides should incorporate cultural construction into the school. The important content of enterprise cooperation shall be taken as the premise and guidance of deepening cooperation.

From the research, we found the problems existing in the process of school enterprise cooperation, especially in the context of the reform of agricultural reclamation, how to establish a technology innovation system with enterprise as the main body, market-oriented and deep integration of industry, university and research, solve the development dilemma of colleges and universities, realize the continuous improvement of education quality, and build a new comprehensive strategic cooperation co-construction relationship. At the same time, with the gradual deepening of the connotation construction of application-oriented universities, school enterprise cooperation develops from single specialty and single field to in-depth development, so as to clarify the positioning and functions of the government, enterprises and schools in the school enterprise cooperation, and then construct a new path of school enterprise cooperation and co-construction, which is of great significance to the development of colleges and universities, personnel training and the improvement of relevant policies and systems by the government strong practical significance.

\section{Funding}

Heilongjiang Bayi Agricultural University (CN) (Award Number: 2041080001).

\section{Conflicts of Interest}

The authors declare no conflicts of interest regarding the publication of this paper. 


\section{References}

China News Network National "Eleventh Five Year Plan” Development Plan.

Educator (2019). 2019 Budget Revenue Statistics of Colleges and Universities Directly under the Ministry of Education.

Liu, G. B. (2017). Path Analysis of Local Agricultural Universities to Improve their Ability to Serve Social Development: A Case Study of Henan Agricultural University. Education Perspective, No. 10, 22-25.

Liu, Y. F., \& Liu, J. L. (2009). Comparison of Foreign School Enterprise Cooperation Modes. Journal of Shanxi Radio and Television University, No. 4, 104-105.

Lu, B. (2018). Integrated Promotion: Basic Principles for Improving Vocational Education and Training System. China Vocational Education, No. 6.

People's Daily (2018). Jointly Create a Fresh Practice Ecology.

$\mathrm{Su}, \mathrm{C} . \mathrm{N}$. (2018). Theory and Practice of Building University Industry Promotion Center under Enterprise Trusteeship. Heilongjiang Higher Education Research, No. 6, 79-82.

Wang, X. Y. (2016). Higher Education Reform Mode and Experience Reference in Foreign School Enterprise Cooperation. Heilongjiang Higher Education Research, No. 8, 51-53.

$\mathrm{Xu}, \mathrm{Y}$. T. (2018). Research on Government, University and Market Coordination Mechanism under the Background of Higher Education Supply Side Reform. Heilongjiang Higher Education Research, No. 2, 61-65. 